\title{
SOME MECHANISMS OF CONTROLLED MORAINE DEVELOPMENT, ANTARGTICA
}

\author{
By R. B. Rains and J. Shaw \\ (Department of Geography, University of Alberta, Edmonton, Alberta, Canada T6G ${ }_{2} \mathrm{H}_{4}$ )
}

\begin{abstract}
Contemporary processes of moraine development at the margins of polar glaciers encompass a wide range of subtly different mechanisms. Two types of "controlled" moraine evolution, applicable to hummocks and transverse moraine ridges, are identified from Wright Lower Glacier and Webb Glacier, southern Victoria Land, Antarctica. Type I moraine complexes involve a relatively abundant supply of supraglacial debris, the development of transverse thrust blocks in the ablation-zone ice and the subsequent re-arrangement of ablation debris in ablation cusps and on inactive thrust blocks. Relict landform suites, apparently formed in this manner, reveal large coarse-grained hummocks inset behind moraine ridge remnants.

Type 2 moraines may develop where the supply of supraglacial debris is meagre but the growth of ablation cusps concentrates primarily englacial debris into small irregular hummocks. The gravel component of this debris is usually of finer texture than for type I deposits, reflecting abrasion/attrition effects of prior englacial transportation. Transverse moraine ridges may or may not be associated with type 2 hummocks, depending on local variations of ice motion, ice decay, and debris supply.
\end{abstract}

RÉsumé. Quelques mécanismes de développement contrôlé des moraines en Antarctique. Les processus contemporains de développement des moraines sur les marges des glaciers polaires comprennent une gamme étendue de mécanismes entre lesquels existent de subtiles différences. Deux types de moraines "contrôlées" ont été caractérisés sur le Wright Lower Glacier et sur le Webb Glacier, au Sud de la Victoria Land en Antarctique. Les complexes morainiques du premier type comportent un apport relativement abondant de matériaux supra glaciaires, le développement de barrages transversaux de poussée et le réarrangement consécutif des produits de l'ablation en pointes d'ablation et sur des barrages de poussée inactifs. La morphologie des délaissés, apparemment formés de cette manière, font apparaître des hummocks à gros grains enchassés dans les cordons morainiques subsistants.

Les moraines du second type se développent lorsque l'apport de matériaux supraglaciaires est maigre, mais que la croissance des pointes d'ablation concentre des matériaux d'origine intraglaciaire en petits hummocks irréguliers. La composition granulométrique de ces matériaux est d'ordinaire de structure plus fine que celle des moraines du premier type en raison des effets d'abrasion/attrition du transport intraglaciaire primitif. Les rides morainiques peuvent ou non être associées avec des hummocks du second type, selon les variations locales du mouvement de la glace, de la fusion et de l'apport en matériaux.

Zusammenfassung. Einige Mechanismen der gesteuerten Entwicklung von Moränen in der Antarktis. Die derzeitigen Vorgänge der Moränentwicklung an den Rändern polarer Gletscher umfassen einen weiten Bereich fein differenzierter Mechanismen. Zwei Typen der "gesteuerten" Moränentwicklung, die auf Moränenbuckel und -querrücken anwendbar sind, wurden am Wright Lower Glacier und am Webb Glacier in südlichem Victoria Land, Antarktika, erkannt. Moränenkomplexe vom Typ I sind gekennzeichnet durch eine relativ reichliche Zufuhr an Oberflächenschutt, durch die Entwicklung transversaler Schubblöcke im Eis der Ablationszone und die dadurch bedingte Neuanordnung des Ablationsschuttes in Ablationskegeln und auf inaktiven Schubblöcken. Fossile Formenfolgen, die offensichtlich auf diese Weise entstanden sind, zeigen grosse, grobkörnige Buckel, eingelagert hinter Reststücken von Moränenrücken.

Moränen vom Typ 2 können sich dort entwickeln, wo die Zufuhr an Oberflächenschutt dürftig ist, aber das Wachsen von Ablationskegeln ursprüngliche Innenmoräne in kleine unregelmässige Buckel zusammenfasst. Die Kieskomponente dieses Schuttes hat gewöhnlich eine feinere Textur als in Ablagerungen vom Typ I, was auf Abrasionswirkungen während des vorausgegangenen Transportes im Eis zurückzuführen ist. Das Auftreten von Moränenquerrücken mit den Buckeln vom Typ 2 hängt von lokalen Änderungen der Eisbewegung, vom Eiszerfall und von der Schuttzufuhr ab.

\section{INTRODUCTION}

The formation of moraines by polar glaciers which are wholly or partly frozen to their bed is related to various modes of debris acquisition, transportation, and deposition. Early studies often assumed debris transport along glacier shear planes to supraglacial positions (Bishop, I957). However, Weertman (I96I) objected to the shear-plane hypothesis on the grounds that there are commonly too many debris bands to be accounted for by shearing. In addition, he showed that the spacing and geometry of the bands are not compatible with a shearing mechanism. He proposed a primary acquisition mechanism whereby subglacial materials are frozen on to the glacier base. Such sediments, which may retain most of their initial characteristics, are thus incorporated into a glacier as discrete bands containing interstitial ice. 
Other debris bands, containing a smaller proportion of debris, are "supersaturated" in terms of ice volume. Boulton (1970) proposed that the latter originate at the crest of bedrock protrusions being over-ridden by glaciers. A combination of regelation ice, formed in the lee of the protrusion, and refreezing of extraneous melt water was considered responsible for the preservation of such bands down-glacier from their points of origin. Selby (1972) suggested that englacial debris bands in the glaciers of the McMurdo dry valleys, Antarctica, resulted from ice-marginal accretion of melt water and associated sediments. Apron incorporation must also contribute to the debris content of these glaciers (Shaw, 1977). Englacial debris of more irregular disposition than dirt bands may be initially incorporated in a number of ways. Within the disproportionately extensive accumulation zones of the dry valleys' glaciers, the concave-up ice surfaces often overlap talus slopes and, occasionally, near-vertical free faces. While evidence for the direct entrainment of sub-marginal debris is lacking, rock-fall and debris-creep material may encroach on to the glacier surface and eventually be transmitted to englacial/subglacial positions via crevasse systems.

In the relatively small ablation zones of polar and sub-polar glaciers, englacial and subglacial debris may be brought to the glacier surface in a number of ways: by shear planes and rising flow lines (Bishop, I957; Weertman, r961; Boulton, I967; Hooke, r970; Drozdowski, 1977); by the gradual exposure of cryoconitic debris concentrations, and by the intersection of snout-zone crevasses, containing some debris, with the lowering ablation surface. In addition, supraglacial debris, thick enough to be insulative and thus prohibit cryoconitic in-melting, may be transported to the snout zone without necessary significant dispersal. The differential thickness of ablation debris may, therefore, result from various combinations of subglacial and supraglacial debris sources. In turn, it has been suggested that "controlled" moraine forms and sediment complexes result when the supraglacial sediment controls the rates of ablation and, consequently, the topography of the ablating ice (Boulton, 1970; Drozdowski, 1977). Hooke (1970) stressed that this topographic control may occur under steady-state conditions, and that both ablation rates and the vertical component of glacier flow must be considered.

A further mechanism for moraine formation by cold-based glaciers involves increased volumes of englacial debris in zones of englacial folding and shearing associated with compressive flow. Maintenance of these high debris volumes during ablation results in moraines which are directly related to the kinematics of ice flow at the margin, and are relatively independent of ablation processes. Such moraines from Antarctica were described by Shaw (197.7), and a similar origin was proposed recently for transverse moraine ridges in Sweden (Minell, r 977).

This paper focuses on contemporary moraines which appear to be composed primarily of supraglacially transported debris. These moraines are "controlled" in that their form is largely a product of the supraglacial topography, but, unlike previously described supraglacial controlled complexes, the initial controlling ice topography usually precedes the concentration of supraglacial debris. Examples of relict moraine systems which appear to have formed in this manner are also briefly described.

\section{CONTEMPORARY EXAMPLES}

\section{Wright Lower Glacier}

Wright Lower Glacier is an extension of Wilson Piedmont Glacier into the eastern end of Wright Valley (Fig. I). Lake Brownworth, a small pro-glacial lake, occurs at the glacier terminus. The ablation zone in the vicinity of the lake includes a series of escarpments which face down-glacier and trend approximately parallel to the ice margin (Fig. 2). The scarp faces are about $5^{-10} \mathrm{~m}$ high and are offset such that individual scarps have limited lateral extent. The surface texture up-glacier from the escarpments is dominated by an intricate dendritic network of supraglacial stream channels. Melt water in the zone of escarpments is directed 


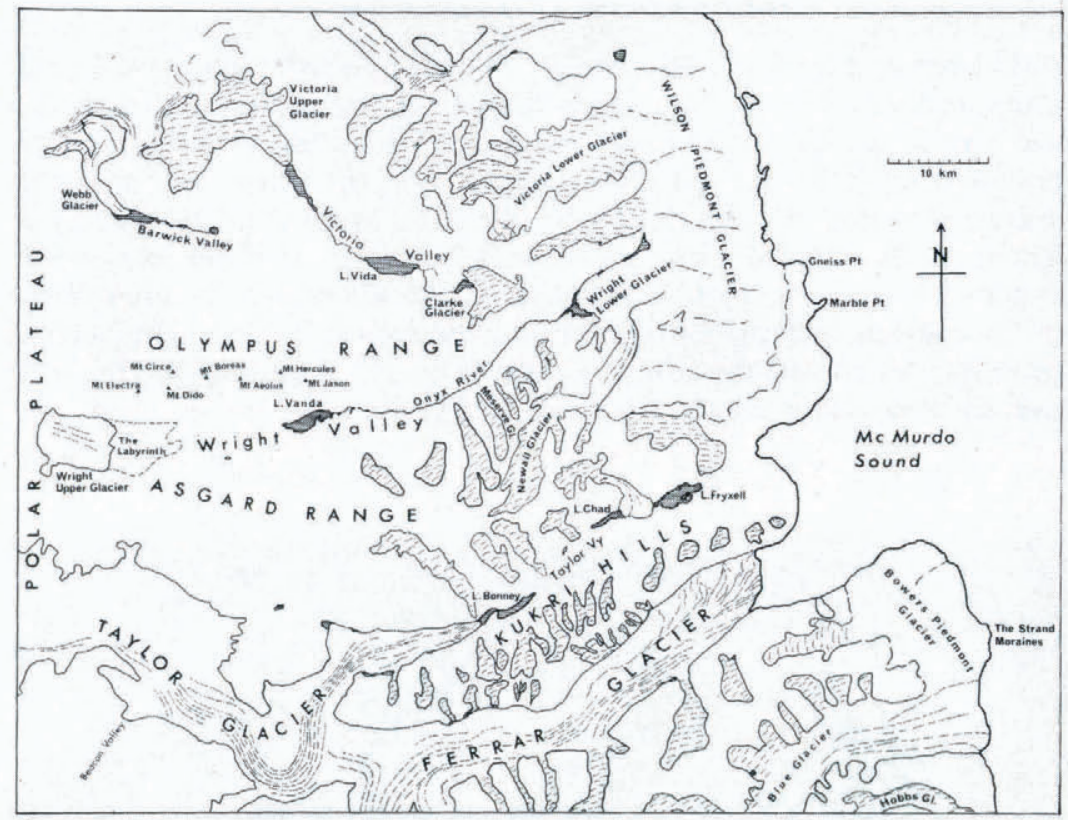

Fig. I. The McMurdo dry valleys, Antarctica.

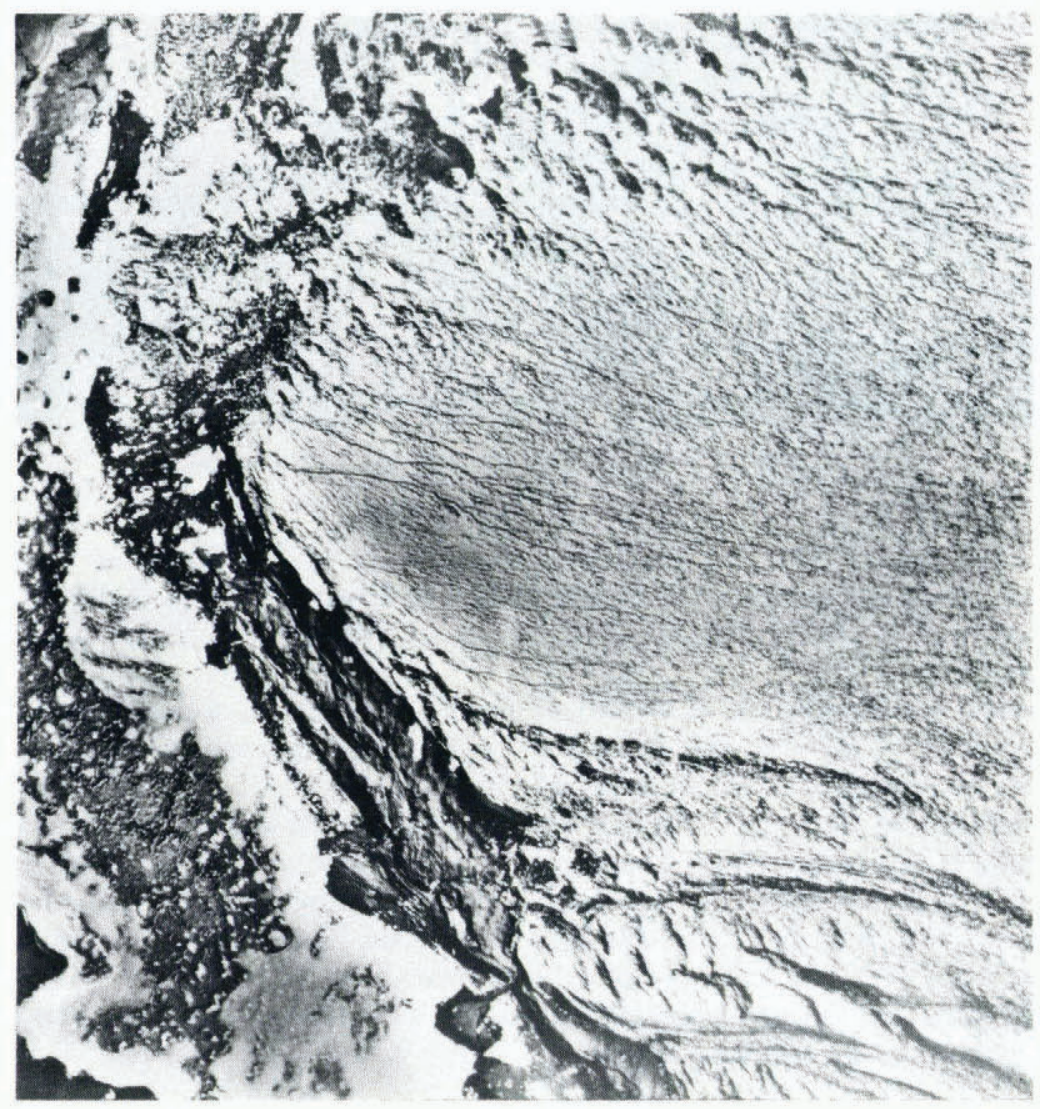

Fig. 2. Vertical view of part of the Wright Lower Glacier ablation zone, snout, and Lake Brownworth. 
along the base of scarps and forms a trellis pattern of valleys which is elongated parallel to the ice margin. The interfluve zone shows a series of intersecting ablation cusps $5-10 \mathrm{~m}$ in diameter and about $\mathrm{I} \mathrm{m}$ deep. Figure 3 illustrates a scarp with ablation cusps close to the crest and a complex of glacio-fluvial and morainic sediments on the valley floor at the scarp base. Ablation-stake measurements between King Pin Nunatak and the ice margin show the area to have a negative mass balance with approximately $20 \mathrm{~cm}$ of water equivalent loss per annum (Anderton and Fenwick, I976). Foliation at the ice margin is marked by bands of relatively high dirt content and dips up-glacier at angles up to $80^{\circ}$ from the horizontal. The foliation can be seen cross-cutting the ablation cusps (Fig. 3). Superimposed ice in the form of stream and pond ice is common within the scarp-foot valleys.

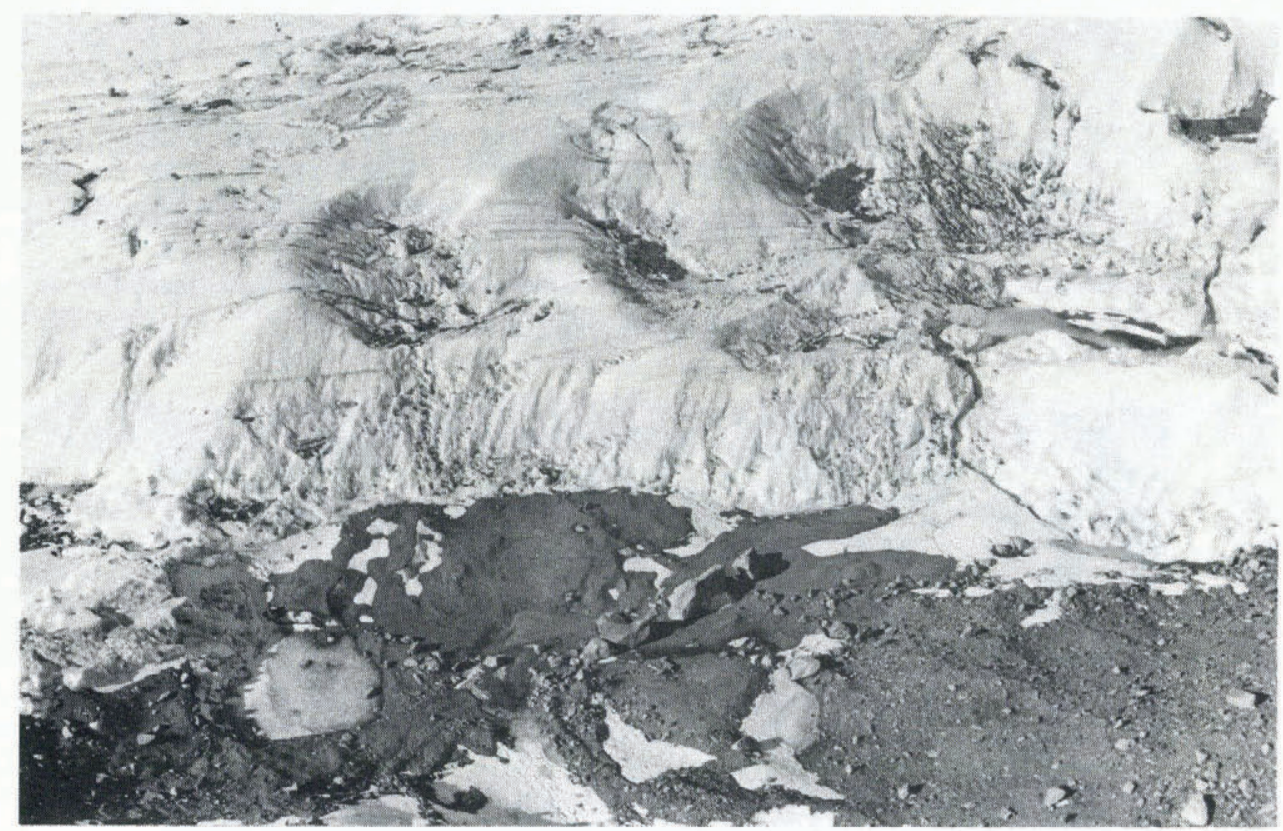

Fig. 3. Wright Lower Glacier ablation cusps and sediment complex.

A diverging train of supraglacial debris emanates from King Pin Nunatak and forms prominent moraines at the ice margin. The formation and characteristics of these moraines will now be described.

Where an ice scarp intersects the path of supraglacial debris from King Pin Nunatak, accumulation occurs as scree at the scarp foot. Continued accumulation at the scarp base shows that the rate of supply of debris from up-glacier is greater than the rate at which debris is removed from below the scarp. Simple backwasting of the scarp cannot account for the volume of debris at the scarp base. Consequently, supraglacial material must be carried to the scarp crest by glacier flow. As the material is not removed at an equivalent rate from below the scarp, there must be a flow differential between ice up-glacier and down-glacier of the scarp face. These observations can be best explained by a mechanism of thrusting in which the scarps represent the leading edges of thrust blocks. These blocks become increasingly inactive as new blocks develop up-glacier. 


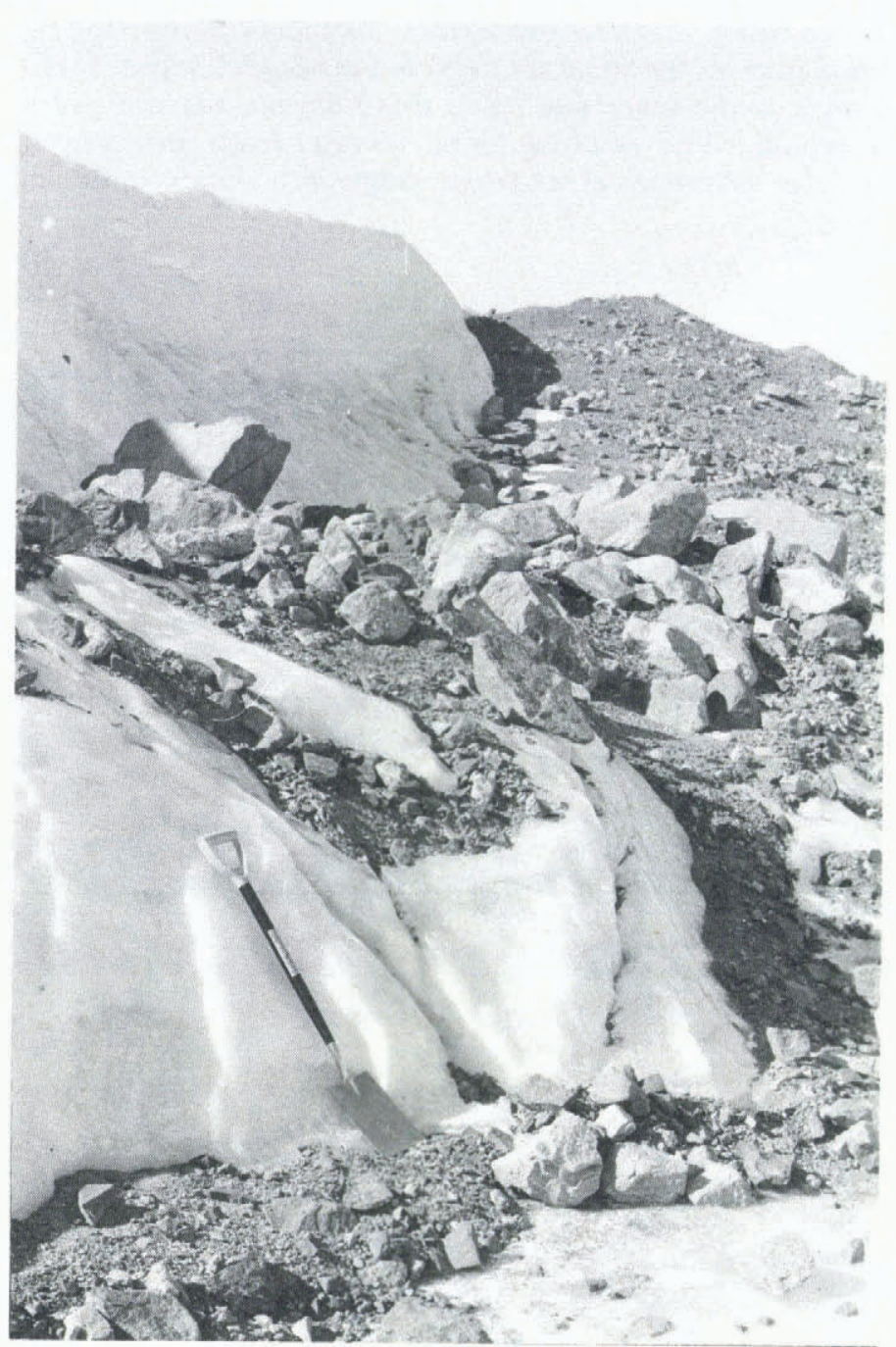

Fig. 4. Thrust block scarp face and supraglacial debris, Wright Lower Glacier.

Debris accumulation against the scarp face is analogous to the development of scree at the foot of a wasting slope (Bakker and Le Heux, r946). The influence of the debris on ablation will affect the form of the underlying ice which, by analogy with a wasting bedrock slope, will form a convex slope. The debris may completely cover the scarp face or may extend only part way up to the face. Both types are illustrated in Figure 4. Two cross-sectional forms may be evident at the time the thrust block, if present, becomes inactive (Fig. 5). These forms depend on the amount of supraglacial debris. In the first type, the thickness of debris over the tread is comparable with that over the scarp. Downwasting due to ablation of the ice core results in a general lowering of the surface. The dominant conditions affecting the final surface relief are the greater thickness of debris at the scarp base and the differential thickness of debris related to the ablation cusps. These conditions lead to a transverse ridge with a distal slope 
at the angle of rest (the proximal slope may be at or less than the angle of rest) and hummocky areas immediately up-valley marking the former ablation hollows (Fig. 5). With a sparse debris cover, ablation rates on the tread are expected to be much higher than those beneath the protective debris cover at the scarp foot. The tread downwastes and eventually isolates the scarp scree from behind. The resulting slope reversal leads progressively to an initially asymmetrical, but later symmetrical ice-cored ridge with slopes at the angle of rest. The

Type 1 controlled moraines

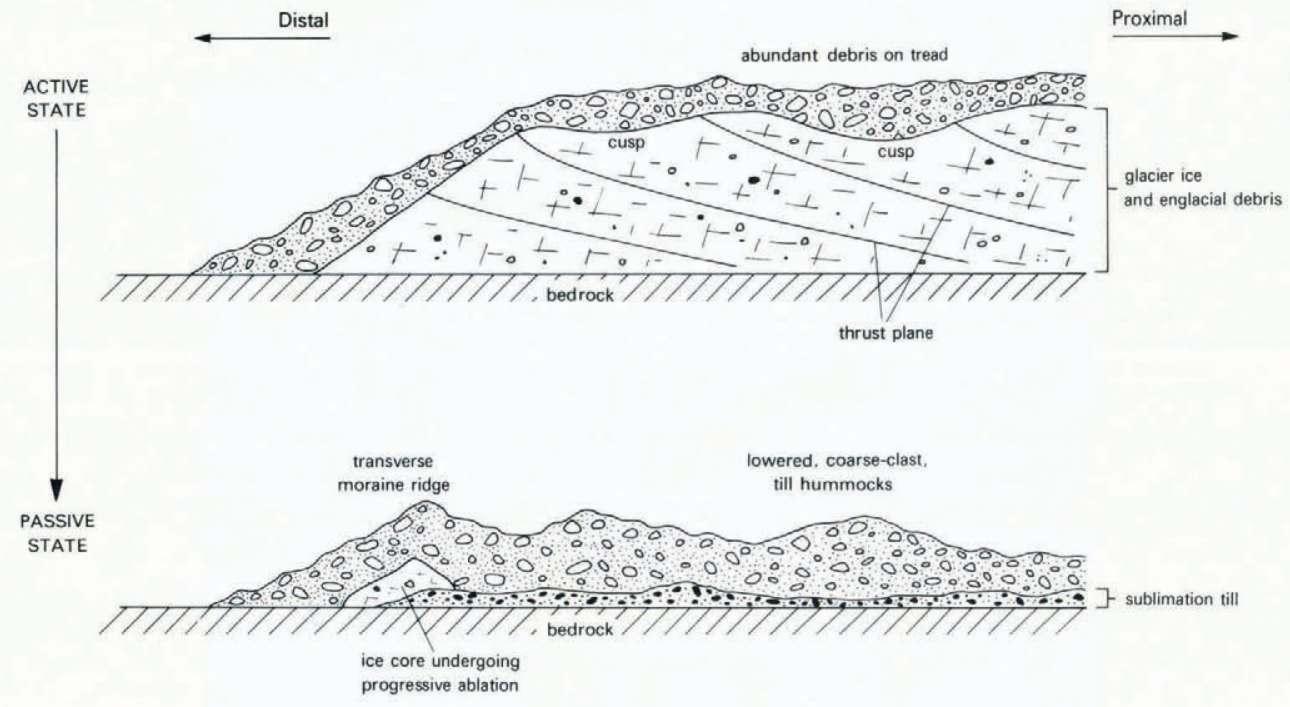

Type 2 controlled moraines

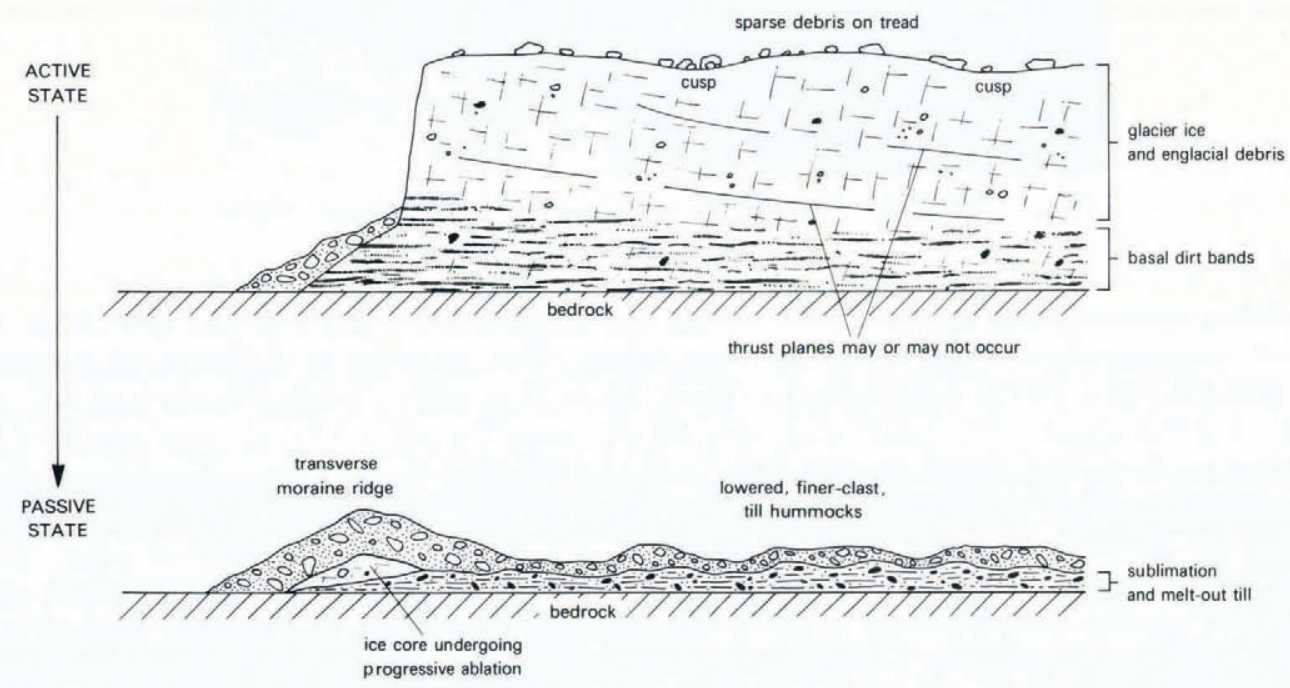

Fig. 5. Two main types of controlled moraine development. 
final, non-ice-cored stage depends on the combined influence of the shape of the ice core and the distribution of mantling debris.

The successive development of thrust blocks and deposition of debris against the leading face may result in a sequence of transverse moraines. Between adjacent scarps are zones of stream and pond development in which stratified sediments may be deposited. With the addition of glacio-fluvial deposition in thermokarst caves (Healy, 1975) through the ice-cored ridges, a complex inter-relationship is expected between till of supraglacial origin and stratified sediments.

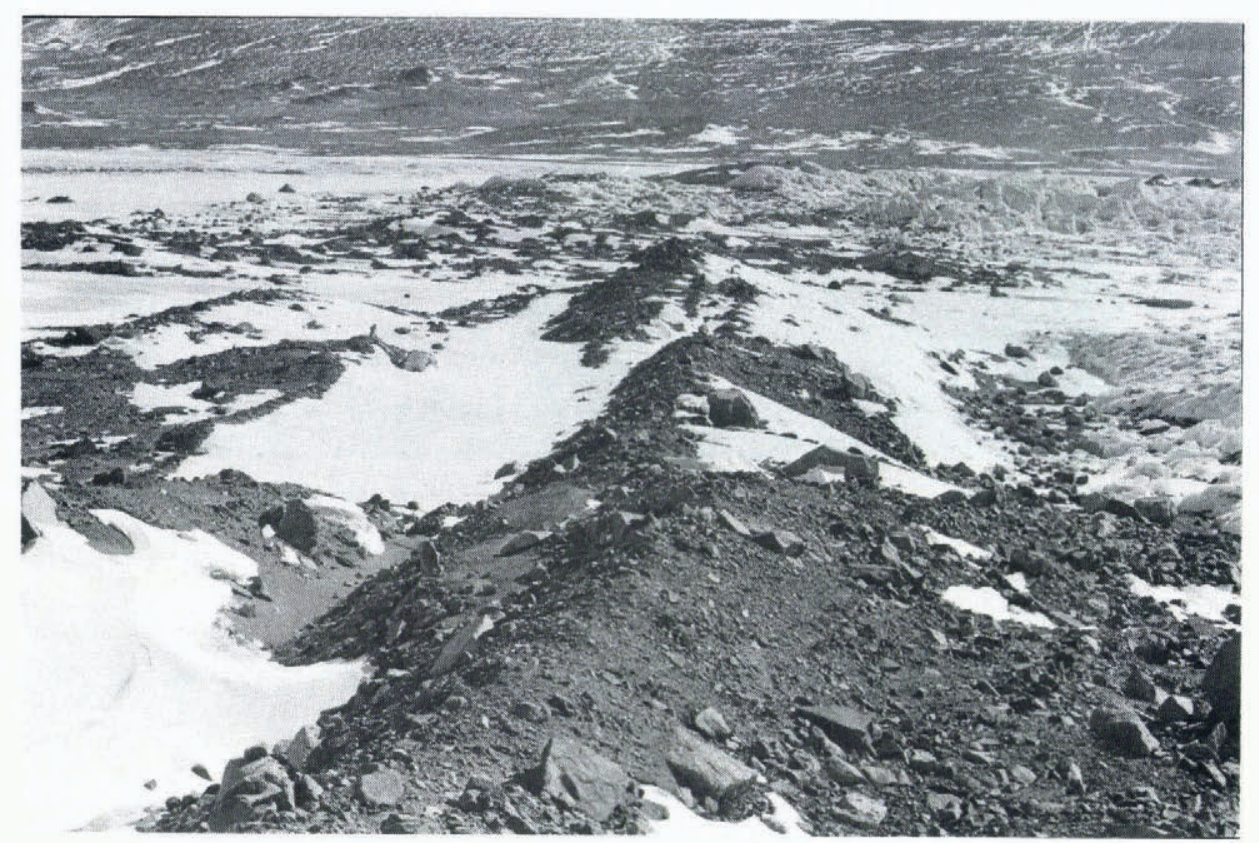

Fig. 6. Distal, type I controlled moraine ridges, Wright Lower Glacier.

Predictions of the expected future characteristics of the pro-glacial area can thus be made on the basis of the conditions observed at the present active glacier margin. A series of transverse moraines should show distal slopes at or close to the angle of rest. The most distal moraines should have the lowest relative relief owing to more advanced ablation of their ice cores. Some variation is expected on this height trend as a result of differences in height of initiating scarps and volumes of debris contributing to the moraines. Profiles of moraines measured at right-angles to the glacier margin show the expected trend in height, with distal slope angles close to $30^{\circ}$ (Fig. 6; see also Rains and Selby, 1972). The most distal set of moraines (Fig. 6) shows offset crests and a relatively subdued surface micro-relief with most of the large blocks partially buried by finer material. More proximal ridges are higher and have a fresher, more active appearance (Fig. 7). Undercutting of the proximal sides of the ice-cored moraines by melt-water streams reveals the internal structure beneath their treads. A debris cover of approximately I $\mathrm{m}$ in thickness, which consists of angular blocks with a sandy matrix, overlies a relatively clean ice core, which may be of glacier or superimposed ice. The debriscovered tread surface is hummocky with individual hummocks up to $10 \mathrm{~m}$ in diameter and $2 \mathrm{~m}$ in height. The melt-water trough contains a complex of angular morainic material and 


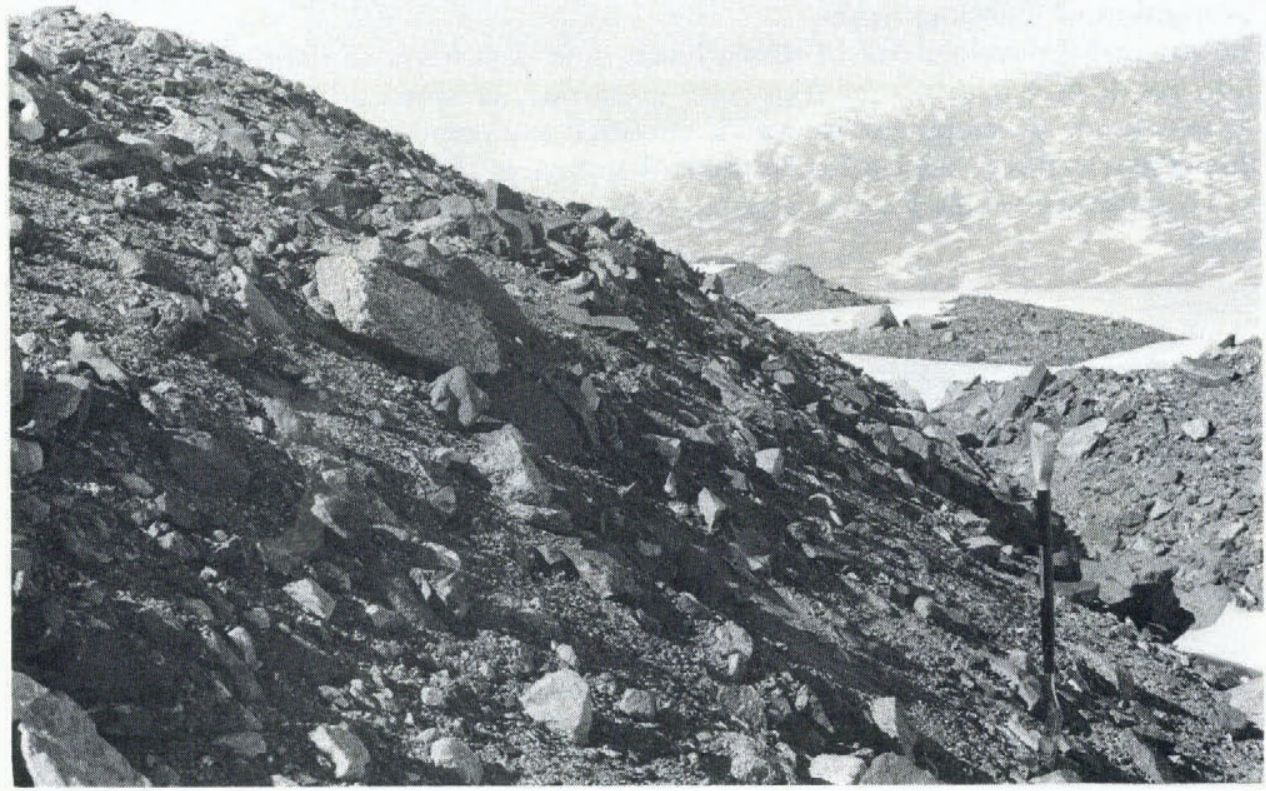

Fig. 7. Proximal, type I controlled moraine ridge, Wright Lower Glacier. The slope above the spade is the distal slope of the moraine.

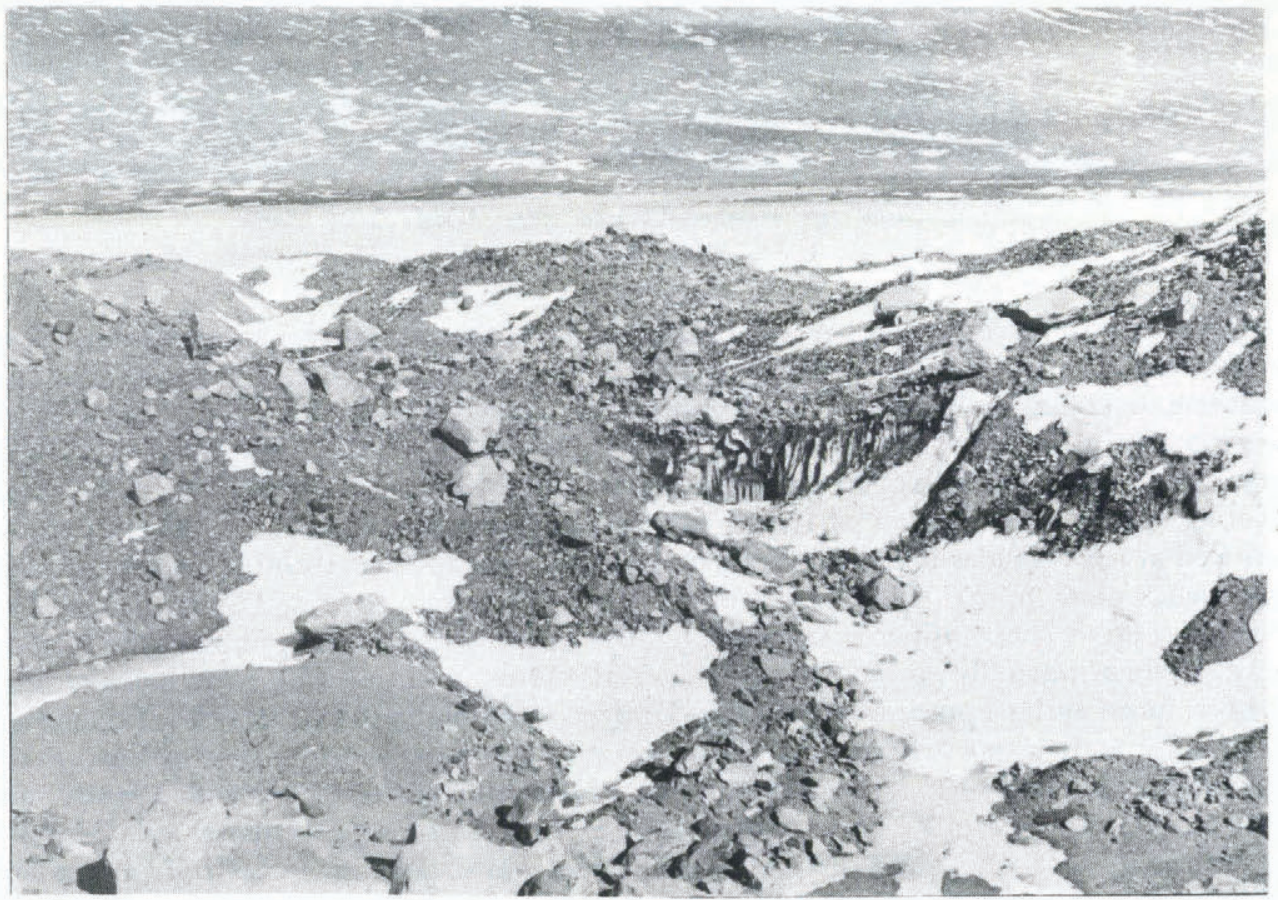

Fig. 8. Proximal moraine, tread and trough characteristics, Wright Lower Glacier. A thermokarst cave is shown near the centre of the photograph. Note the patches of sorted material. 
glacio-fluvial sediment. These characteristics of the tread and adjacent trough are shown in Figure 8. The fresh appearance, with numerous perched blocks and the thermokarst cave which drains the trough, indicate the active nature of the proximal moraines. Close inspection of the moraines shown on the air photograph of Figure 2 reveals a distinctive scalloped pattern on the tread surface. This pattern reflects the underlying ablation cusps. Thicker debris in the cusps reduces ablation rates and is eventually responsible for the relief inversion which produces the hummocky topography.

An idealized view of a landscape and sediment complex resulting from the above processes is given in Figure 9. This diagram represents almost perfect preservation of individual features. However, it must be remembered that the whole complex is deposited over a body of ice and further disturbances may occur during the ablation of this ice.

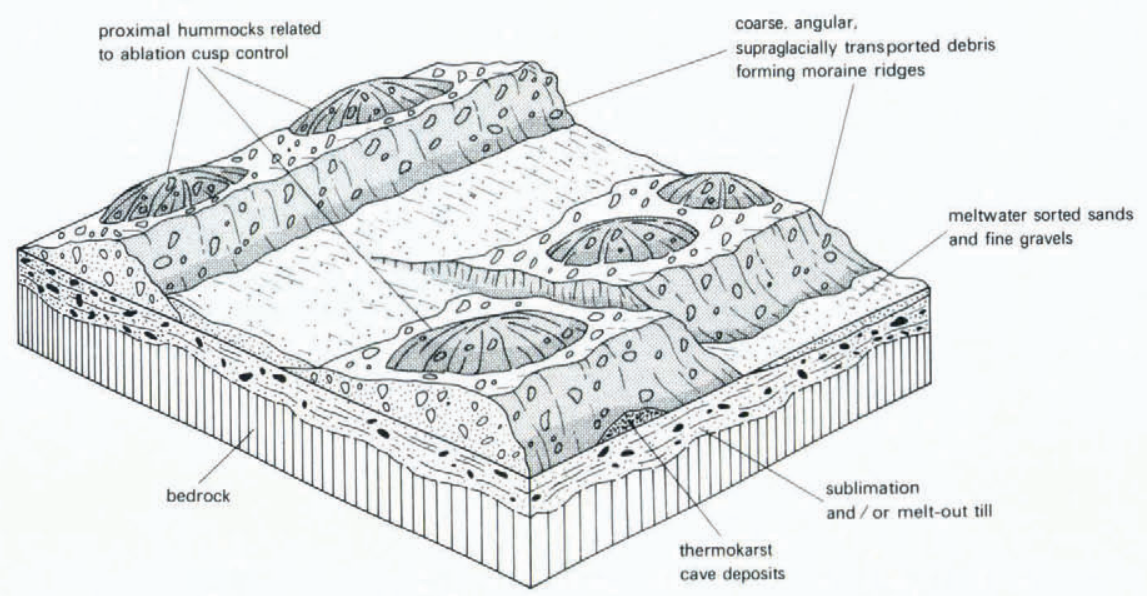

Fig. 9. Idealized landscape and sediment complex of controlled moraine development.

\section{Webb Glacier}

Ice from a series of large alpine cirques, and from the East Antarctic ice sheet (via Webb Icefall), constitutes Webb Glacier in Barwick Valley (Fig. I). Pro-glacial Webb Lake partly submerges the present glacier snout so that terminal moraines, if existing, are obscured. However, a variety of extensive, ice-cored lateral moraines, plus less extensive supraglacial moraine, is present along parts of the glacier margin (Calkin, 1964, 1971; Rains and Selby, I972).

In contrast to the ablation-zone surface of the previously described Wright Lower Glacier, that of Webb Glacier is comparatively smooth with very restricted development of supraglacial melt-water channels. Cryoconitic in-melted materials are, however, particularly evident below the smooth ablation surface and supraglacial debris is localized. Basal ice and debris bands are best exposed along part of the south-western glacier margin (Fig. Io), although in general the near-vertical, marginal ice cliff typical of polar-glacier ablation zones is poorly developed for Webb Glacier. Features of interest shown in Figure ro are: first, the bulk of the ice from the glacier surface down to about $6 \mathrm{~m}$ from the bed is debris-poor; secondly, minor fold (A) and fault structures (B) occur in the basal debris/ice bands; and thirdly, mounds of coarse-grained debris occur at more or less random intervals along the basal margin of the glacier. At location A (Fig. I0), the ice appears to be over-riding a large mound of debris with resulting gentle folds in the englacial dirt bands. At location $\mathrm{C}$, a much smaller debris mound appears to rest against the glacier base without any apparent distortion 


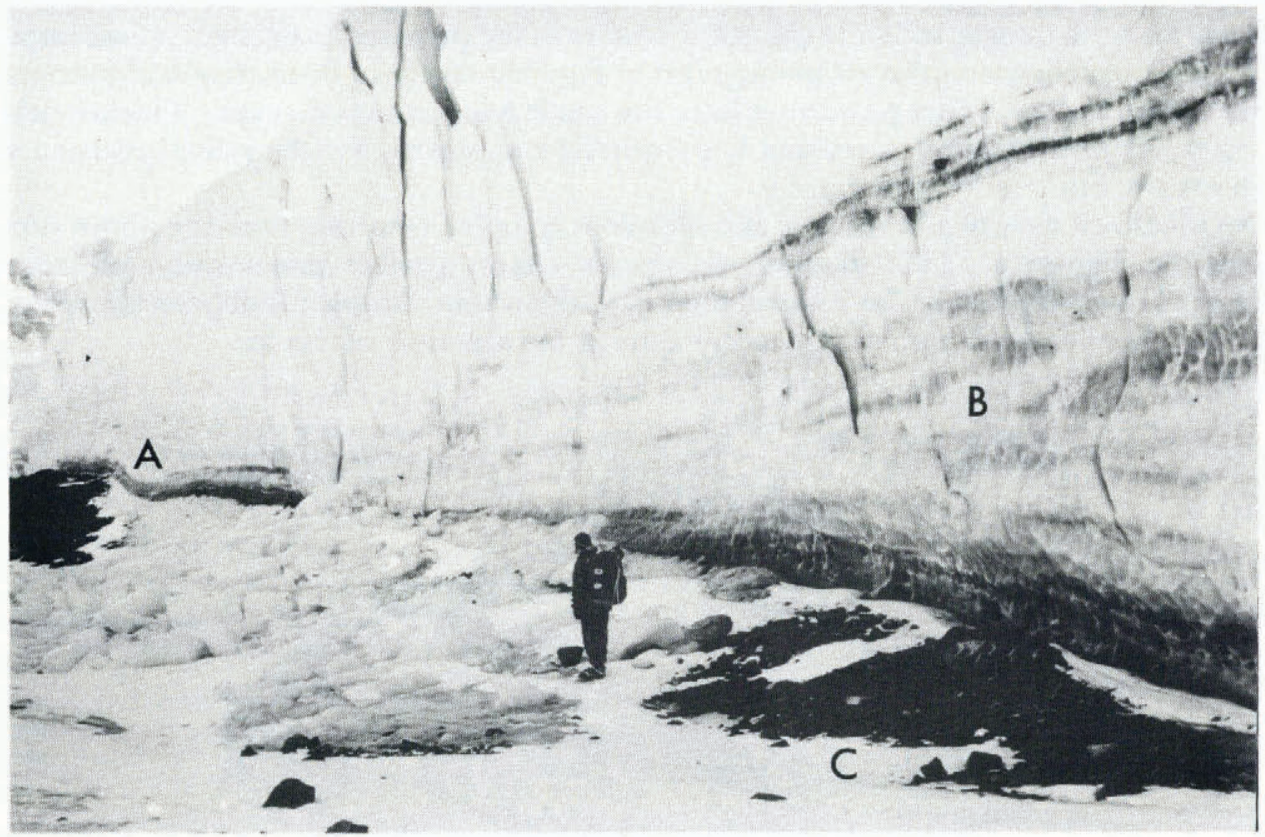

Fig. 1o. Part of the Webb Glacier margin.

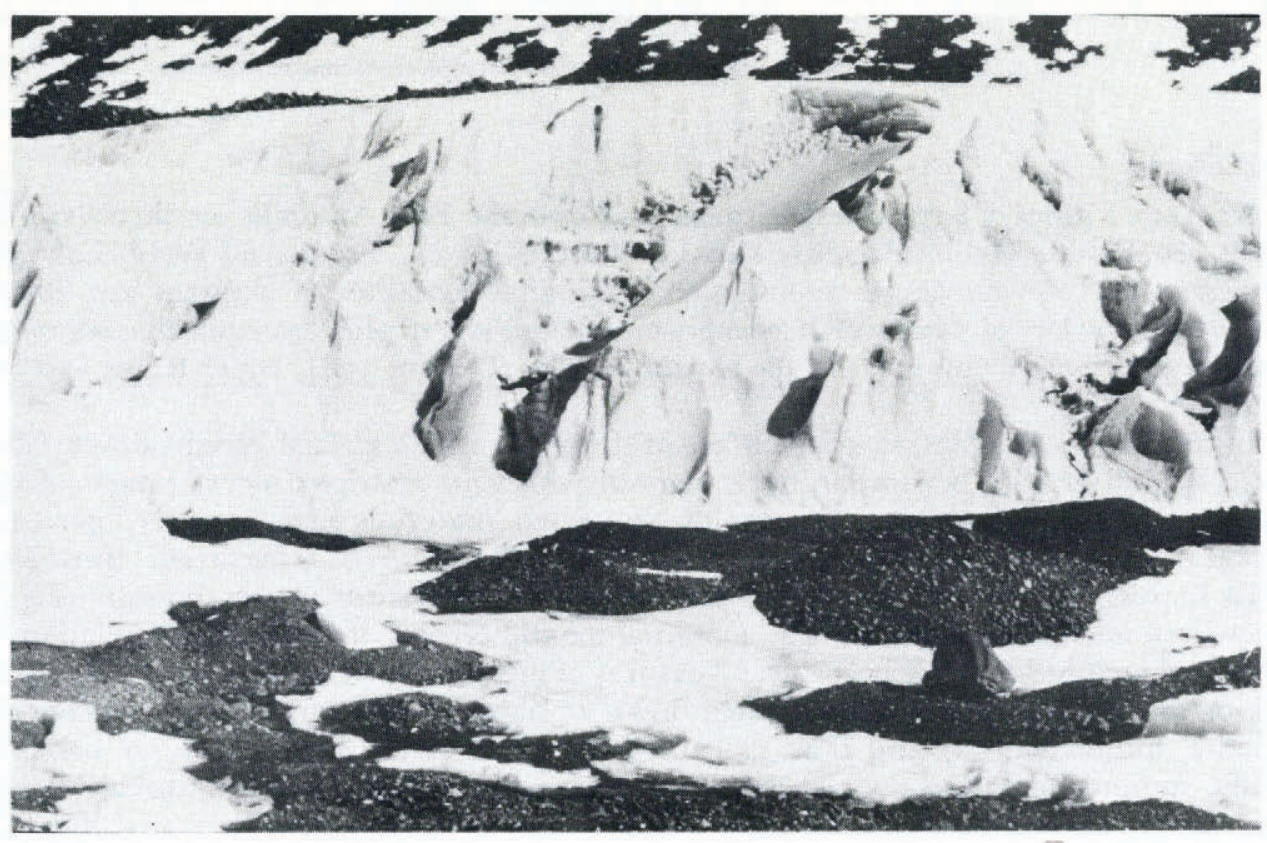

Fig. II. Ablation cusps and type 2 controlled moraine, Webb Glacier. 
of basal ice and debris layers. Comparable moraine mounds occur elsewhere in the dry valleys, for example, alongside Walcott and Victoria Upper Glaciers. However, in all such cases it is problematical whether these are a product of contemporary apron incorporation and/or push-moraine processes. Alternatively, they may be old moraine cones now undergoing exhumation or engulfment by slowly retreating or advancing glaciers. The occurrence of distinctive moraine cones in Barwick and McKelvey Valleys, many kilometres from the nearest glaciers, indicates that the latter relict-moraine interpretation is quite feasible. We should be aware of the possibility, therefore, that present ice-marginal landforms are not necessarily all products of contemporary processes.

Webb Glacier maintains four marginal zones of ablation cusps and supraglacial melt-water channel development. These are somewhat similar to, but much less extensive than, the Wright Lower Glacier examples described earlier. Figure I I illustrates the juxtaposition of melt-water-producing ablation cusps, sorted gravel cones, and coarse clasts which occur on the northern margin of the Webb Glacier snout.

The abraded, smoothed nature of the gravels suggests that these have undergone appreciable englacial/subglacial transportation before release and partial water-sorting in this icemarginal position. These sediments display a strong contrast with the predominantly larger, more angular clasts of supraglacial origin to be discussed later in this paper. The character of this cusp zone strongly resembles that of Wright Lower Glacier shown in Figure 3 with two exceptions. The first is that englacial dirt bands have no appreciable dip. This, and the icestratigraphic evidence of Figure Io, suggests that thrust-block development is of negligible significance for the Webb Glacier case. Secondly, the northern margin of Webb Glacier is not supplied with supraglacial debris to any significant extent. The ablation cusps are therefore relatively debris-deficient. Thus, type 2 of Figure 5 is closely approximated by the sedimentary environment shown in Figure I I with the exclusion of a transverse moraine.

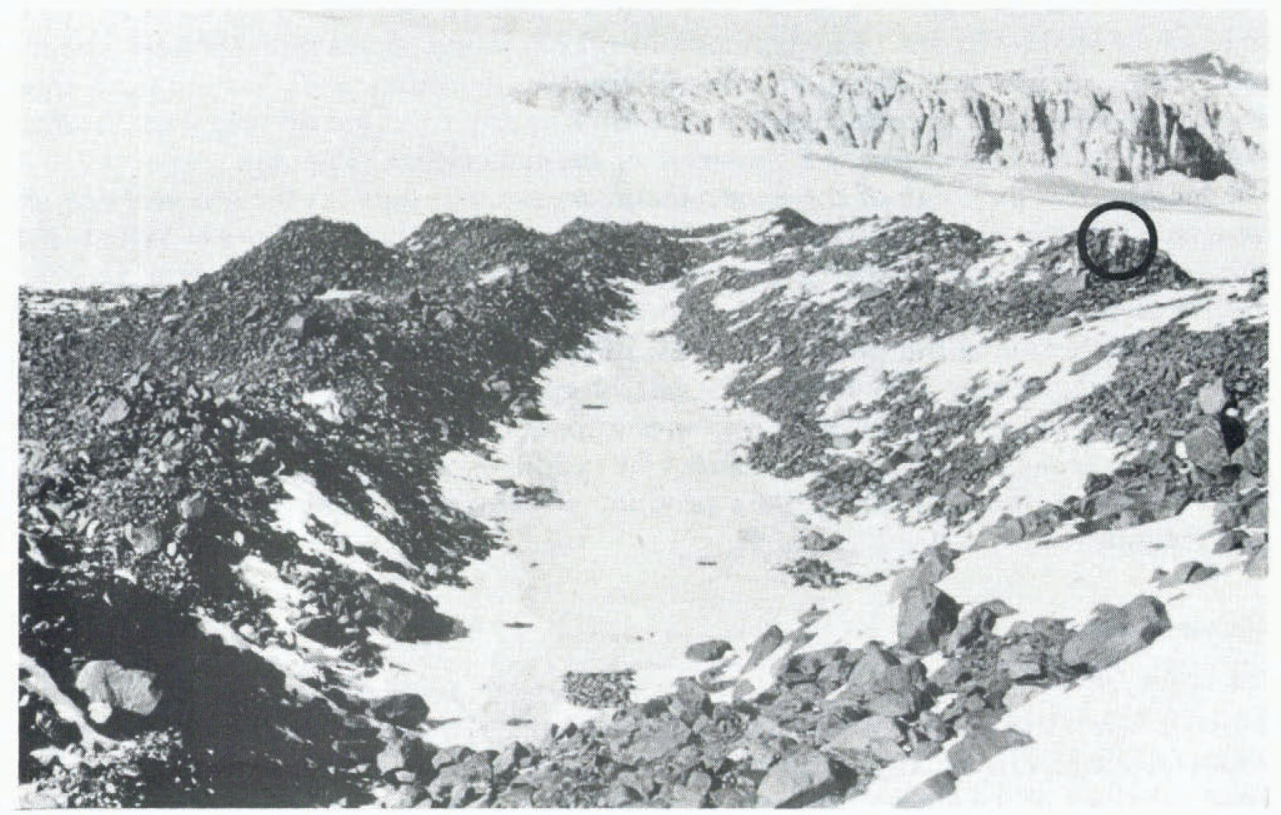

Fig. 12. Proximal, lateral moraine ridges, upper Webb Glacier. (6o cm long back-pack circled for scale.) 
Selby (1972) outlined a useful categorization of predominant glacier and moraine associations for the Antarctic dry valleys. Noting that "few dry valley glaciers have large moraines in contact with ice at the present time" (Selby, I972, p. 249), he singled out Radian and Webb Glaciers as major exceptions. Very extensive lateral moraine fields appear to rest on the Webb Glacier surface for almost $4 \mathrm{~km}$ along its southern and western margin, from below Webb Icefall to within $4 \mathrm{~km}$ of the terminus. These moraines were described briefly by Calkin (1964, r971) and in greater detail by Rains and Selby (1972). The moraines are largely ice-cored with associated melt-water channels, superimposed ice ponds, perched blocks and numerous till cones or mounds. In the main, the moraine surfaces are at present a few metres higher than the immediately adjacent, smooth glacier surface. Small, supraglacial melt-water channels mark the contact between the most proximal moraine debris and the clean glacier ice. Short channels also occur in some of the troughs between adjacent moraine ridges. At least three distinct moraine ridges are prominent with intervening troughs of widely varying widths and surface forms (Figs $12-14$ ). The proximal ridges in places exhibit strong slope asymmetry, distal slopes being steeper than proximal ones, but elsewhere asymmetry is negligible. The ridges are progressively more subdued, both in terms of local relief and slope steepness, with distance from the present glacier margin.

It seems most unlikely that the debris comprising the veneer has been subjected to appreciable englacial or subglacial transport. The coarse, very angular clasts are, in most respects, similar to debris on adjacent talus slopes. Ferrar Dolerite sills in Barwick Valley produce abundant talus, whereas Beacon Sandstone outcrops provide more meagre supplies (see middle ground, Fig. 14). Selby (1972) has stressed the importance of talus as a primary sediment source for dry valley glaciers and there is little doubt that this applies particularly well in the Webb Glacier case. It remains to account for the variety of moraine ridge and mound features shown in Figures 12-I4. The sharp-crested till ridges, with intervening troughs, shown in Figures 12 and 13 lie parallel to the glacier margin several kilometres up-valley from the present snout. Although their slope asymmetry is perhaps suggestive of thrust-block control normal to the ice margin, it is difficult to reconcile this mechanism with the exceptionally smooth glacier surface and the very limited evidence of fault structures in the basal debris bands of Webb Glacier. Furthermore, insofar as much of this moraine field apparently rests on Webb Glacier ice wedging out laterally towards the valley wall, normal push-moraine development seems an improbable mechanism. Southward, rounded till ridges and hummocks maintain the typical coarse-grained character of these moraines (Fig. I4).

The present interpretation of these spectacular moraines is that (a) the primary acquisition of supraglacial debris was from rockfalls and talus creep off adjoining slopes of Willett Range, (b) the concentration of thicker debris along belts parallel to the ice margin was mainly induced by glacier flow having higher velocities towards the valley axis. A more pronounced topographic expression of the proximal ridges, plus progressive inactivity of the distal ridges, has resulted, and (c) type $\mathrm{I}$ of Figure 5 is partly approximated by these moraines. In this instance, though, the most prominent till cones appear on the moraine ridges and not within the intervening troughs. These cones cannot be readily explained in terms of ablation-cusp development but rather appear to be a product of debris-thickness controls of differential ice-core ablation.

\section{Relict EXAMPLES}

\section{Victoria Upper Glacier}

Between Lake Vida and the present Victoria Upper Glacier snout (Fig. I) exceptionally numerous terminal, lateral, and "controlled" moraines occur. These are related to earlier icemarginal positions of the glacier. Figure ${ }_{5} 5$ illustrates a variety of moraine complexes in part of the valley. Details of the lateral and "controlled" moraines at site A (Fig. I5) are shown in 


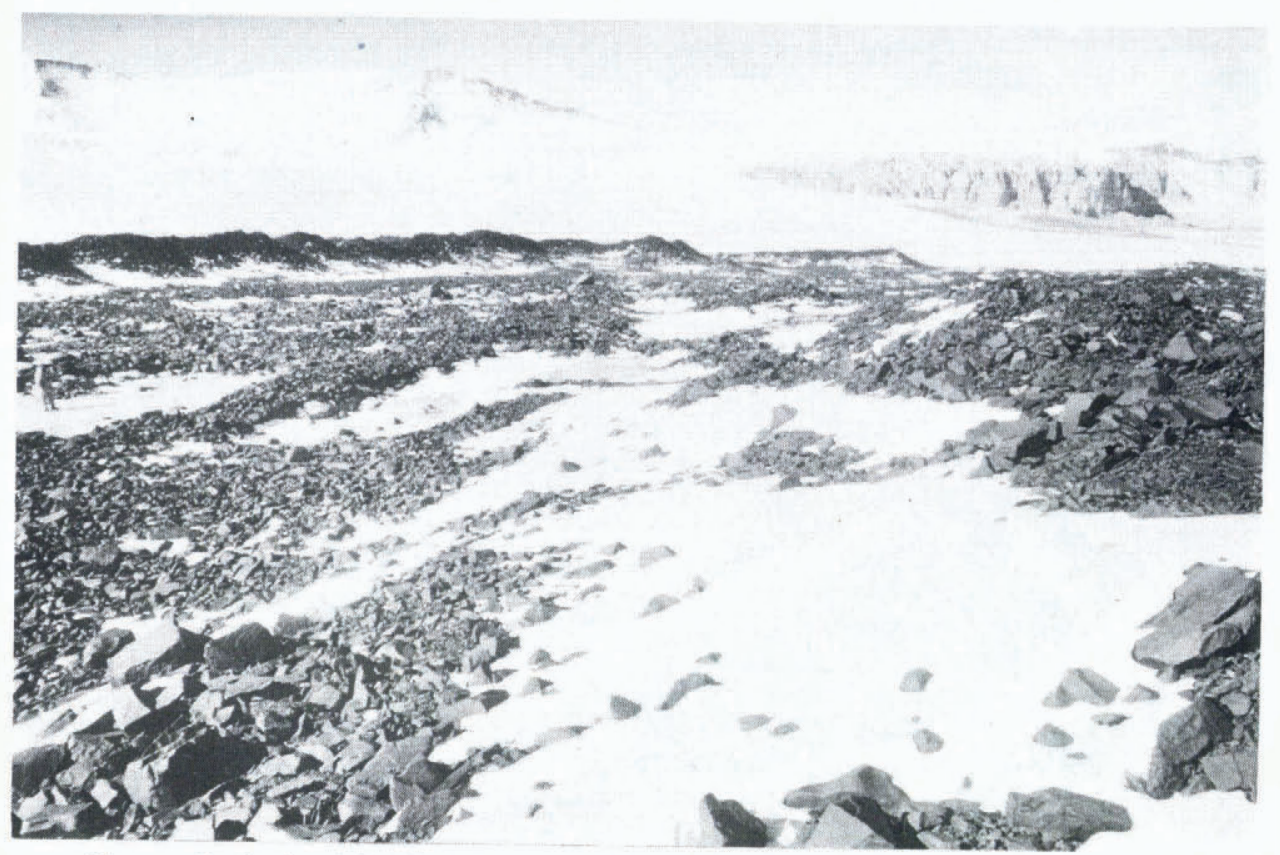

Fig. 13. Proximal and distal lateral moraine ridges with broad intervening trough, upper Webb Glacier.

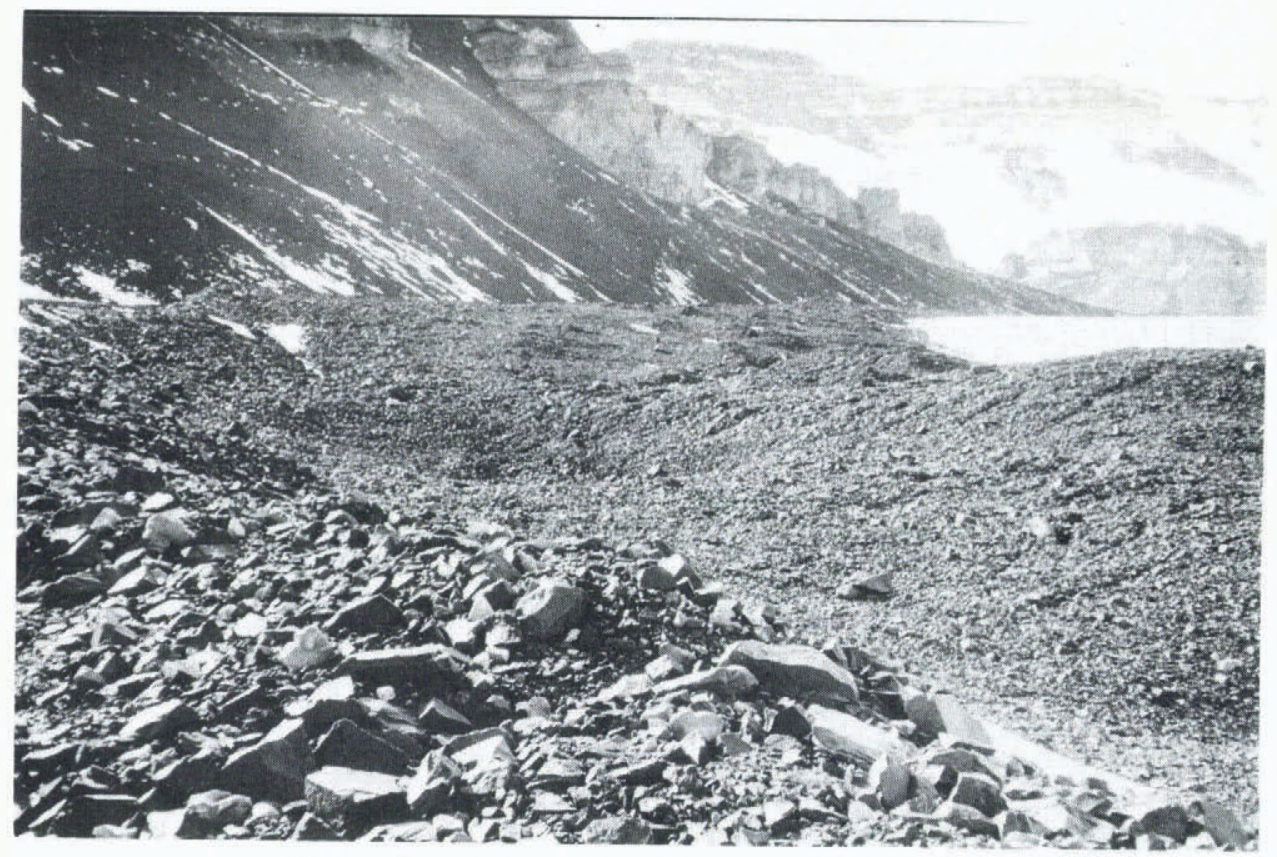

Fig. I4. Lateral moraine ridges and troughs, middle Webb Glacier. 


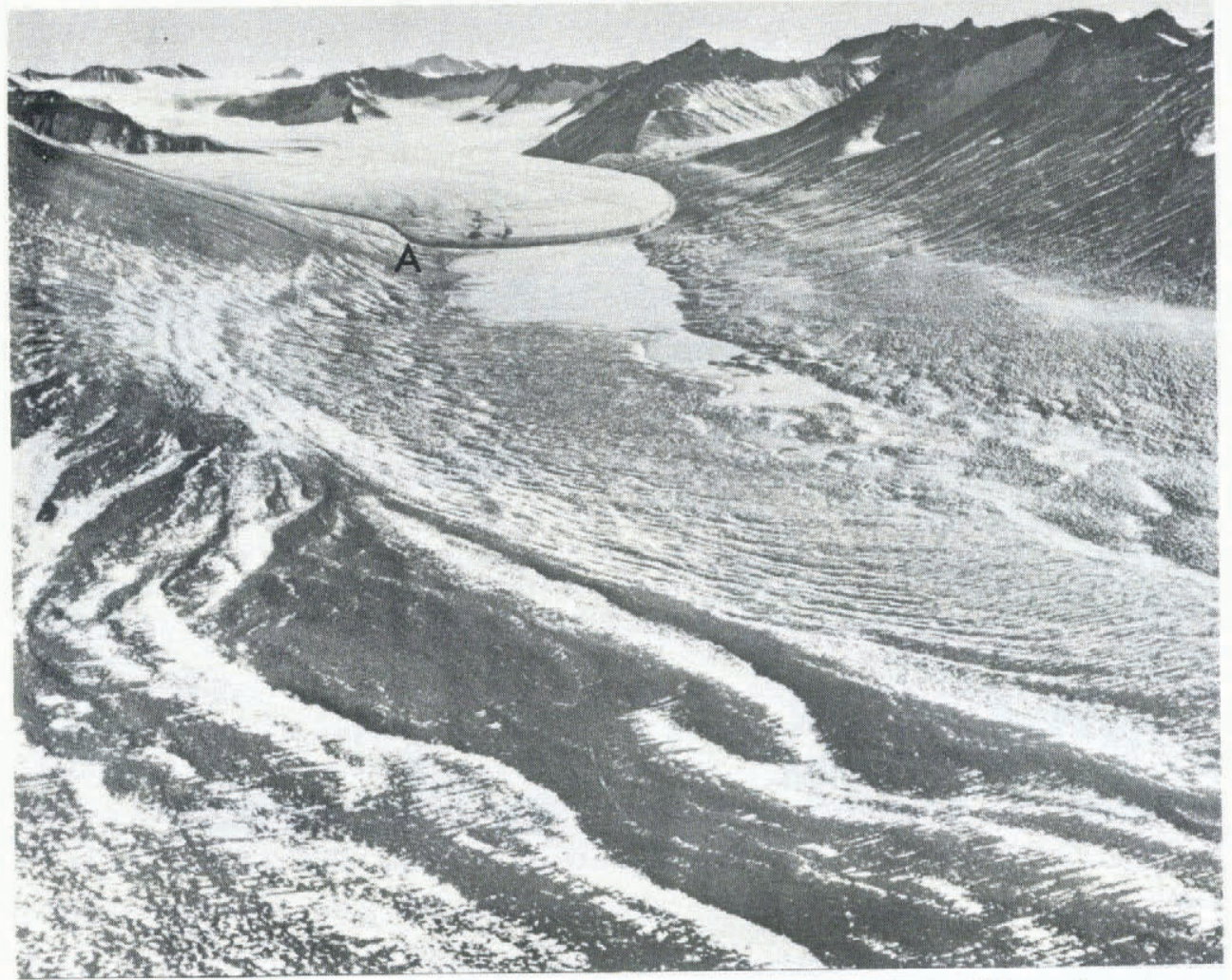

Fig. 15. Victoria Upper Glacier, lake, and moraines. " $A$ " indicates the site of Figure 16.

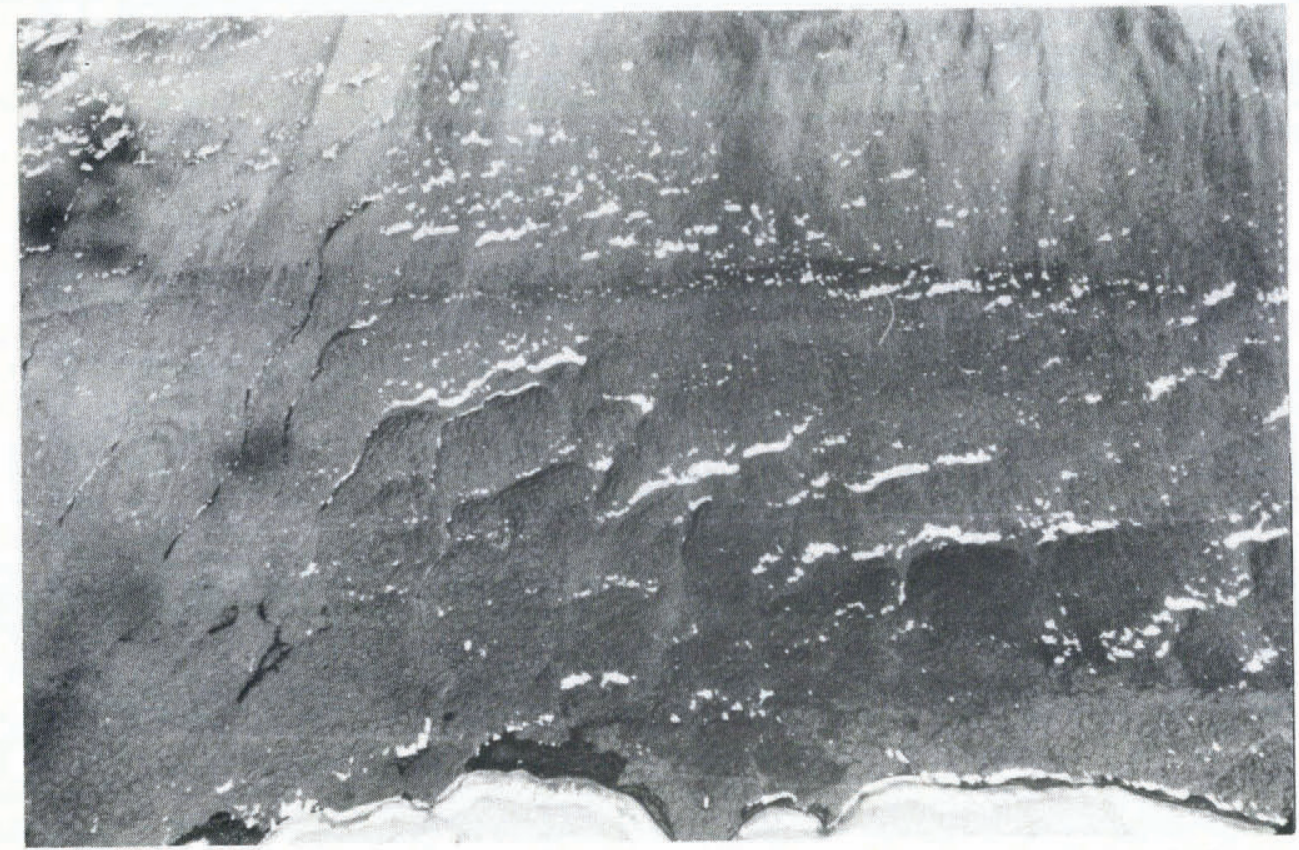

Fig. 16. Vertical view of lateral moraine ridge, controlled moraine hummocks, and Victoria Upper Lake shore. 
Figure I6. Prominently displayed are "controlled" moraine hummocks down-slope of a subdued lateral moraine ridge above the west shore of Victoria Upper Lake. The forms and relationships of these relict features are closely analogous to the contemporary complex of Wright Lower Glacier (Fig. 2).

\section{Conglusion}

Interpretations of polar-glacier sedimentary environments should be based on observations of presently evolving depositional complexes. This is particularly appropriate in studies of Antarctic glacigenic sediments for two main reasons. First, many of the Antarctic dry valleys contain suites of glacial deposits which are of great antiquity (see for example, Calkin and others, 1970; Denton and others, 197I). The identification and interpretation of these deposits are hampered because modifications of the related landform associations by periglacial processes have been substantial. Secondly, because such relict deposits are permafrosted to the surface during winters and to within a few tens of centimetres of the surface during summers, observations on the internal characteristics of the sediments are quite restricted. Therefore, the interpretation of ancient glacial environments is largely reliant on modified surface forms and, secondarily, on modified near-surface sediment characteristics. Neither of these can be expected to reveal reliable primary sedimentary evidence of past processes and responses.

Recent studies illustrate that contemporary processes of moraine development at polarglacier margins encompass a wide range of subtly different mechanisms. This paper describes two additional types of "controlled" moraine evolution applicable to hummocky and transverse-ridge moraine complexes. The first type requires a relatively abundant supply of supraglacial debris, the development of transverse thrust blocks in the ablation-zone ice, and the subsequent re-arrangement of ablation debris as marginal ablation cusps and/or inactive thrust blocks evolve. Relict landform suites, apparently formed in this manner, reveal large, coarse-grained moraine hummocks inset behind remnants of moraine ridges.

The second type may develop where the supply of supraglacial debris is meagre but the growth of ablation cusps concentrates primary englacial debris into small irregular mounds. The gravel component of this debris will usually be of finer texture than that of type I hummocks. One reason for this is the abrasion and attrition effects of prior englacial debris transportation. Transverse moraine ridges may or may not be associated with type 2 hummocks, depending on local variations of ice motion, ice decay, and debris supply. Intuitively, it seems that the preservation of type I "controlled" moraines is much greater than for type 2 deposits. Relict suites in Victoria Upper Valley, for example, give some support to this interpretation.

\section{Acknowledgements}

The work reported here derives from observations made during two University of Waikato Antarctic expeditions. The authors acknowledge with gratitude financial support from New Zealand University Grants Committee grants to Drs M. J. Selby and T. R. Healy, University of Waikato. 


\section{REFERENCES}

Anderton, P. W., and Fenwick, J. K., comp. 1976. Dry valleys, Antarctica, 1973-74. Wellington, Ministry of Works and Development for the National Water and Soils Conservation Organisation. (Hydrological Research: Annual Report No. 37.)

Bakker, J. P., and Le Heux, J. W. N. 1946. Projective-geometric treatment of O. Lehmann's theory of the transformation of steep mountain slopes. Verhandelingen der Koninklijke Nederlandsche Akademie van Wetenschappen. Afd. Natuurkunde, Tweede Sect., Deel 49, No. 5, p. 533-47.

Bishop, B. C. 1957. Shear moraines in the Thule area, northwest Greenland. U.S. Snow, Ice and Permafrost Research Establishment. Research Report 17.

Boulton, G. S. 1967 . The development of a complex supraglacial moraine at the margin of Sørbreen, Ny Friesland, Vestspitsbergen. Fournal of Glaciology, Vol. 6, No. 47, p. 717-35.

Boulton, G. S. 1970. On the origin and transport of englacial debris in Svalbard glaciers. Fournal of Glaciology, Vol. 9, No. 56, p. $213-29$.

Calkin, P. E. 1964. Geomorphology and glacial geology of the Victoria Valley system, southern Victoria Land, Antarctica. Ohio State University. Institute of Polar Studies. Report No. 10.

Calkin, P. E. r97I. Glacial geology of the Victoria Valley system, southern Victoria Land, Antarctica. (In Crary, A. P., ed. Antarctic snow and ice studies II. Washington, D.C., American Geophysical Union, p. 363-412. (Antarctic Research Series, Vol. 16.))

Calkin, P. E., and others. 1970. Glacial history of Wright Valley, southern Victoria Land, Antarctica, by P. E. Calkin, R. E. Behling, and C. [B. B.] Bull. Antarctic Journal of the United States, Vol. 5, No. 1, p. 22-27.

Denton, G. H., and others. 1971. The late Cenozoic glacial history of Antarctica, by G. H. Denton, R. L. Armstrong, and M. Stuiver. (In Turekian, K. K., ed. The late Cenozoic glacial ages. New Haven and London, Yale University Press, p. 267-306.)

Drozdowski, E. 1977. Ablation till and related indicatory forms at the margins of Vestspitsbergen glaciers. Boreas, Vol. 6, No. 2, p. 107-14.

Healy, T. R. 1975. Thermokarst-a mechanism of de-icing ice-cored moraines. Boreas, Vol. 4, No. 1, p. 19-23.

Hooke, R. L. 1970. Morphology of the ice-sheet margin near Thule, Greenland. Fournal of Glaciology, Vol. 9, No. 57 , p. $303^{-24}$.

Minell, H. 1977. Hog's-back moraines in Harrejokko, northern Sweden. Geologiska Föreningens $i$ Stockholm Förhandlingar, Vol. 99, Pt. 3, No. 570, p. 264-70.

Rains, R. B., and Selby, M. J. 1972. Relatively young moraines of the Webb Glacier, Barwick Valley, Victoria Land, Antarctica. (In Stokes, E., ed. Proceedings of the seventh New Zealand Geography Conference, Hamilton, August 1972. [Christchurch], New Zealand Geographical Society, p. 235-45.)

Selby, M. J. 1972. The termini and moraines of glaciers in the McMurdo dry valleys, Antarctica. (In Stokes, E., ed. Proceedings of the seventh New Zealand Geography Conference, Hamilton, August 1972. [Christchurch], New Zealand Geographical Society, p. 247-57.)

Shaw, J. 1977. Till body morphology and structure related to glacier flow. Boreas, Vol. 6, No. 2, p. 189-201.

Weertman, J. I961. Mechanism for the formation of inner moraines found near the edge of cold ice caps and ice sheets. Journal of Glaciology, Vol. 3, No. 30, p. 965-78. 